\title{
Effect of Nongovernmental Economy Development on Chinese Urbanization Process
}

\author{
Jun Wang \\ School of Marxism \\ Wuhan University of Science and Technology \\ Wuhan, China 430065
}

\author{
Yuzhen $\mathrm{Wu}$ \\ School of Marxism \\ Wuhan University of Science and Technology \\ Wuhan, China 430065
}

\begin{abstract}
Nongovernmental economy has necessary connection with urbanization. The development of nongovernmental economy is the most basic impetus of urbanization development. Nongovernmental economy continuously promotes urbanization process through technology, capital and institutional factor. This article puts forward some countermeasures to improve urbanization of our country on the basis of analyzing nongovernmental economy.
\end{abstract}

Keywords—nongovernmental economy; urbanization; countermeasures

\section{INTRODUCTION}

Report of the 18th National Congress of CPC clearly puts forward "stick to walk the road of new type of industrialization, informatization, urbanization and agricultural modernization with Chinese characteristics, promote deep integration of informatization and industrialization, benign interaction of industrialization and urbanization, mutual coordination of urbanization and agricultural modernization and promote synchronous development of industrialization, informatization, urbanization and agricultural modernization." It also emphasizes, "We shall unswervingly encourage, support and guide development of non-public economy and ensure all kinds of ownership economy equally use production factors, fairly participate in market competition and equally receive legal protection". It creates the best investment opportunity for development of nongovernmental economy and further firms the confidence to develop nongovernmental economy. The development of nongovernmental economy certainly will promote the urbanization process of our country.

\section{CONTRIBUTIONS MADE BY NONGOVERNMENTAL ECONOMY FOR URBANIZATION}

Through more than 30 years of cultivation and development since the implementation of the reform and opening-up policy, some nongovernmental economic entities are qualified to participate in urbanization construction no matter on scale or technology. Nongovernmental economy is born in the tide of market economy and has close relationship with market economy. It has the inborn advantage to conform to market rules and draw on advantages and avoid disadvantages.

Fund program: Exploration on Mode and Method of Practical Teaching Link of "Outline" Course in Wuhan University of Science and Technology, school-level project topic (2010072X).

\section{A. Development of Nongovernmental Economy Is the Starting Point of Rural Urbanization}

The development of nongovernmental economy has inseparable relationship with realization of urbanization. In the final analysis, the development of nongovernmental economy gradually expands and lays foundation for urbanization. It is difficult to realize urbanization without booming development of nongovernmental economy, even empty talk. The development of nongovernmental economy includes the development of small and micro businesses, which are cells of cities and towns. According to statistics, since the implementation of reform and opening-up policy, nongovernmental economy of our country has developed greatly. Up to September, 2012, the quantity of private enterprises registered in China has reached to up 10,598,000, with year-on-year growth of $12.6 \%$ and shows thriving vitality and vigor. The registered capital of private enterprises has reached up to 29,800 billion yuran, with year-on-year growth of $21.3 \%$. The average registered capital reaches 28,130 billion yuan, with year-on-year growth of $7.8 \%$. The scale and strength of enterprises are strengthened continuously.

\section{B. Nongovernmental Economy Drives the Increase of Urban Population and Quantity of Employment}

The increase of urban population is an important of urbanization. The increase of employment opportunity and employed population brings increase of urban population. The increase of urban population and quantity of employment mainly benefits from the development of nongovernmental economy. Up to September 2012, the average registered capital of private enterprises registered in our country has a year-on-year growth of $7.8 \%$; scale and strength of enterprises continue to be strengthened, with 21,635,000 investors and year-on-year growth of $11.6 \%$; the ability of obtaining employment is more prominent, with $89,079,000$ employees and year-on-year growth of $9.4 \%$ and the total number exceeds 110 million. In the corresponding period, the total number of households of individual business reaches up to more than 39 million with year-on-year growth of $7.8 \%$. The number of employees reaches up to $84,547,000$ with year-on-year growth of $10.4 \%$. In 2012, the proportion of nongovernmental economy in GDP exceeds $60 \%$. In the first ten months of 2012 the cumulative growth rate of added value of industrial enterprises above privately operated scale is $14.9 \%$. Compared 
with the rate in 2022, although it falls after rise, it still outclasses $6.4 \%$ of state-owned industrial enterprises and average level of $10.0 \%$ of all industrial enterprises.

\section{Nongovernmental Economy Is the Main Force of Urban Development and Construction}

In recent years, the Party Central Committee and the State Council attach great importance to the development of nongovernmental economy and introduce preferential policies such as "36 Articles on Non-public Ownership Economy" and "36 Articles of New Detailed Rules and Regulations on Nonpublic Ownership Economy" to support the development of nongovernmental economy. Nongovernmental economy achieves significant development. At present, there are 10.25 million private enterprises and 38.96 households of individual business, providing $80 \%$ of the jobs in cities and towns and $90 \%$ of newly-added jobs, contributing more than $60 \%$ for GDP and 50\% for tax revenue. Nongovernmental economy has become strong power to drive rapid and steady growth of economy of our country, the main channel to create employment, important source to increase income, active promoter of glorious cause and important basis to improve livelihood of people and social harmony. The political status of nongovernmental economy of our country is also promoted obviously, from "beneficial supplement of public ownership economy" in initial stages for reform and opening-up to "important part of socialist market economy" and gradually become "vital force" and "main force" of economic construction of our country.

\section{Nongovernmental Economy Is Investor and Operator of Municipal Public Utilities in Cities and Towns}

Since the reform and opening-up, because of the requirements of economic development and infrastructure construction of cities and towns, under the guidance of correct policy of the Party Central Committee, government carry out many reforms on investment, construction, operation and management of municipal public utilities in cities and towns. At the same time, nongovernmental economy also enters this field and creates quite a few effective investments, financing methods and construction and operating models. Nongovernmental economy has become important force for investment, construction and operation of municipal public utilities in cities and towns.

\section{E. The Prosperity of Nongovernmental Economy Changes Views and Values and Life-style of Urban Residents}

The urbanization in our country is an economic structure supported by private enterprises, integrating agriculture, industry and business. The structure has comparatively perfect material and cultural service facilities and furthest meets growing material and cultural needs of farmers materially and spiritually, and becomes the center and carrier to enrich and improve material civilization, spiritual civilization and political civilization in the vast rural areas. Under the influence of the powerful three "civilizations", the image of farmers is appearing qualitative change. Farmers and villages and towns in traditional sense are gradually replaced by the concepts of residents, cities and towns.

\section{TENDER CONSTITUTION OF NONGOVERNMENTAL ECONOMY FORMS IMPORTANT ECONOMIC HURDLES OF URBANIZATION DEVELOPMENT}

Urbanization construction is a systematic engineering, the largest domestic demand of China in the future, requiring enormous capital investment and long-term scientific planning. Realizing ambitious goal of urbanization construction and guaranteeing comprehensive construction of moderately prosperous society as scheduled needs joint efforts of all sectors of society including the government, especially needing positive participation of nongovernmental economy as "main force of economic construction".

However, the contribution made by nongovernmental economy in national economic development doesn't match with its status in state investment and construction. The proportion of nongovernmental economy in urban investment in fixed assets exceeds $60 \%$, but the proportion in infrastructure and major projects is still low, only has $20 \%$. These problems existing in development of nongovernmental economy greatly influence urbanization development.

\section{A. Hinder Surplus Rural Labor Force to Transfer to Towns}

The basic criterion to measure the urbanization development level is aggregation ability of surplus rural labor force or rural population, which is also the international standard. The ability of urbanization to gather population mainly relies on development of the second industry and the tertiary industry in cities and towns. The two non-agricultural industries mainly show two forms of enterprise, namely township enterprise and private enterprise. Because township enterprises face structural adjustment and development stagnation after the 1990s, the absorption of surplus rural labor force is saturated and surplus, so many enterprises elbow out or lay off a good deal of existing employees. At present, it is difficult to count on township enterprises to transfer surplus rural labor forces. We can only rely on rapid development of nongovernmental economy. Although nongovernmental economy keeps certain growth rate and development vitality at the present stage, it is very hard for them to gather surplus rural labor force and shoulder the historic responsibility to transfer surplus rural labor force.

\section{B. Hinder Infrastructure Construction in Towns}

Hardware infrastructure construction of water, electricity, road and environmental greening in towns is an important criterion to measure urban development level, but it needs to spend a lot of money in construction and improvement of infrastructure. No matter looking from the perspective of the existing urbanization development policy or practice of urban construction, the capital of urban construction mainly comes from accumulation of their own, and our country doesn't invest a great deal of money in it. For township enterprises, in consideration of the weak growth and low efficiency at present, they cannot take out more funds for construction. In this way, they can only rely on nongovernmental economy with late start and great potential. However, now nongovernmental economy faces many difficulties in accumulation and development of its own and cannot provide quite a few capitals for urban infrastructure construction, which is also the important 
economic reason why the urbanization cannot get rapid development in the middle and later periods of 1990s.

\section{Hinder the Promotion of Economic Function of Towns}

The economic function of a town is embodied on not only the ability to gather and absorb people but also the ability to gather all kinds of production factors and modern service industry in the market and the degree of influence on an area. It is the underlying problem of urbanization development and the "nature" to measure urban development level. If economic function of towns wants to get "qualitative" breakthrough and promotion, the basic supports are scale and level of urban construction and development situation of the existing secondary industry and tertiary industry, which is the material basis for promotion of economic function of towns. The expansion and enhancement of the material basis mainly relies on rapid development of nongovernmental economy no matter at present or in the future. Obviously, at present, the tender constitution of nongovernmental economy restricts promotion of economic function of towns.

\section{Hinder Exertion of Social Function of Towns}

Town is not only an economic center but also political and social activity center of a region and has direct radiation capability and social influence on the surrounding countryside. Towns connect city and countryside and directly go deep into countryside and have the most direct relationship with farmers. It is the last operating platform to implement general and specific policies of the Party and our Nation. At present, social organizations in towns are not perfect and their functions are not complete, either. The reason is that the economic foundation in towns is weak and cannot support daily operation of a perfect social organization. The essential problem is the tender constitution of nongovernmental economy.

\section{E. Hinder Development of All Kinds of Social Undertakings in Fields of Science and Technology, Education and Culture in Towns}

The capital used for development of social undertakings in towns can only come from accumulation of their own. Nongovernmental economy plays an important role in accumulating and undertakes important social responsibilities. But at present, financial resources offered by nongovernmental economy for development of causes in fields of science and technology, education and culture in towns are very limited, so these public social undertakings develop slowly in short supply. On the other hand, the slow development of nongovernmental economy causes the situation that towns cannot gather large population and average per capita income of residents is low, so their demand for consumption in causes of science and technology, education and culture reduces and cannot form virtuous circle with development of social undertakings.

\section{CONCLUSION}

Through more than 30 years of cultivation and development since the reform and opening-up, some nongovernmental economic entities are qualified to participate in urbanization construction no matter on scale or technology. We shall encourage nongovernmental economy to positively participate in urbanization construction and give full play to the effect of "main force".

\section{A. Innovate Development Conception}

In the process of urbanization construction, it is necessary to weaken government interference, improve market competition mechanism and insist marketability operation and actively exert leading function of the market. Break the concept of urban and rural dual status hierarchy, open admittance restriction in the field of investment, establish socialized service system of development of nongovernmental economy, ensure nongovernmental economy can equally and justly participate in national infrastructure construction and major projects no matter on the form or essence, and has the right to equally share the "cake" in new type of urbanization construction.

\section{B. Improve Related Supporting Policies}

Intensify to introduce various supporting preferential policies (such as : Project examination and approval, land supply, admittance of household registration, tax preference, credit aid and special fund support) to encourage nongovernmental economy to participate in urbanization construction and formulate specific implementation rules. It is suggested to establish special supervision and inspection agencies to supervise and evaluate the implementation situation of various preferential policies and related measures on supporting the development of nongovernmental economy, form long-term mechanism and fulfill the commitment of the government to support development of nongovernmental economy.

\section{Expand Financing Channels of Nongovernmental Economy}

Strongly support new financing platforms that "the government enhances the credit, chamber of commerce operates and enterprises guarantee each other" and mechanism construction, deepen the reform of financial service system, encourage to set up private banks to further expand financing channels of nongovernmental economy.

\section{Governments Support Development of Nongovernmental Economy}

Governments at all levels shall focus on supporting a batch of leading private enterprises with good potential for growth in local places, encourage them to actively participate in renovation project, construction of industrial park and new rural construction, make efforts to help them to solve practical difficulties and problems faced by them in key project investment when they participate in urbanization construction, support them to grow rapidly, become strong to fully exert the leading radiation effect. 


\section{E. Insist Industry Leading Effect and Give Play to Radiation and Driving Function of Industrialization}

For areas with low level of industrialization, energetically develop small and miniature non-public enterprises; for large and medium-sized cities with high level of industrialization, accelerate the reform of supporting systems in household registration, employment, housing and education and promote interactive development of industrialization and urbanization.

\section{REFERENCES}

[1] Zheng Wei, Li Yuanhua. Intergrowth Development of Chinese Nongovernmental Economy and Informal Finance-Theoretical and Empirical Analysis [J], Economic Research Guide, 2013(01).

[2] Tong Ling, Jin Zhaihuai. Thinking and Countermeasures of Scientific Development of Nongovernmental Economy in Our Country $[\mathrm{J}]$, Inquiry into Economic Issues [J], 2012(12).

[3] Ding Renzhong, Sun Genjin. Transformation and Development of Nongovernmental Economy of Our Country in New Period [J], Economic Theory and Business Management, 2011(12).

[4] Liu Decheng. Research on Rural Urbanization under Promotion of Nongovernmental Economy-Typical Cases in Zhejiang Province [D], Zhejiang Normal University, 20111.

[5] Huang Mengxia. China's Private Enterprise Development Report [M], Social Sciences Academic Press, 2007.

[6] Liang Xian. Industrialization, Urbanization, Agricultural Enterprise and Nongovernmental Economy [J], Economic and Social Development, 2007(1)

[7] Zhou Pijuan. Research on Internal Mechanism of Nongovernmental Economy Development and Urbanization [J], Journal of Zhongkai Agrotechnical College, 2005(2).

[8] Liu Chuanjiang. Urbanization and Urban and Rural Sustainable Development [M], Science Press, 2004.

[9] Xu Zhihuan. Tender Constitution of Nongovernmental Economy: Economic Hurdles of Small Urbanization Development [J], Economic Review, 2004(11)

[10] Hu Shunyan. China's Urbanization Development Strategy [M], Press of Party School of the Central Committee of C.P.C 